\title{
ANALYSIS OF PARTICULAR PARAMETERS OF A SOCIAL SITUATION OF THE DEVELOPMENT OF A PRE-SCHOOL AGED CHILD IN CONDITIONS OF THE FAMILY AND PRE-SCHOOL EDUCATION INSTITUTIONS
}

\begin{abstract}
The changing conditions of social development give considerable relevance to a study of parameters of a social situation of the development of the individual at the stage of childhood. The aim of the study: research of characteristics of a social situation of the development of a pre-school aged child at the present stage of society. The study was conducted in the cities of Minsk and Zhlobin (The Republic of Belarus); children of preschool education institutions $(n=100)$ and their parents $(n=28)$ participated in the study. Diagnostic tools: "Parents composition", "Choice in action", "Stair", "Finish a story", a conversation on three clusters of unfinished sentences. The results of the empirical study revealed a predominance of non-constructive child-parent interaction in the respondents' families. The analysis of a child's position in a group of an education institution generally revealed the existence of a favourable climate in the given subsystem of relations. Preferences in one or another type of interactions are connected with the selfassessment, a position in a group and a level of awareness of ethical norms and values. Optimization of the main parameters of pre-school aged children interaction is a relevant direction of the support of positive socialization.
\end{abstract}

Keywords: social situation of child's development; preschool age; types of childparent interaction; motivation of social interaction; the institution of preschool education

\section{Introduction}

The transformation of social development characteristics is connected with a change of predominant social practices, external and internal components of relations. The overall growth in uncertainty and instability of socialization conditions (A.G. Asmolov, 2017) and an intensive change of parameters of a social situation of the development in 
the period of childhood (N.E. Veraksa,2018), (Kolominskii, Ya.; Pan'ko, E.; Chesnokova, E.; Nedvetskaya, T., 2015), (Smirnova, E.O.; Lavrent'eva, T.V., 2006), (D.I. Feldshtein, 2012) are noted.

The description of traditional understanding "a social situation of the development" as a specific for each age relationship between a child and a social environment, intermediating socialisation processes, proposed by the founder of a historic cultural theory L.S. Vygotsky (Vygotskii, L.S.,1984), has been defined. Its parameters are actively affected by characteristics of images "adulthood" (Polivanova, 2016, p. 9), a possibility of enactment of social roles played by a child in various relations (Asmolov, 2016, p. 32), a system of requirements imposed on a child by "world of adults" and the rights given to him by this "world" (Veraksa, N.E.; Veraksa, A.N., 2008, p. 19).

In the context of designated directions of the assessment of a social situation of the development in childhood, empirical studies of its parameters become relevant in the context of a possibility to ensure positive socialization in the period of childhood. Herewith, an essential aspect of the study is the availability of methods that allow hearing "child's voice" as a direct subject of socialization and assess a degree of successful interaction in the main subsystems of relations "child-adult" taking into consideration microenvironments that prevail in a child's life (Gogoberidze, A.G.; Novitskaya, V.A.; Atarova, A.N.; Novikov, M.S.; Yafizova, R.I., 2018).

The Republic of Belarus is among the countries with a high level of education of the population. Full coverage of school preparation for five-year-old children has been reached, a high index of child development at an early age is noted (Belarus' na puti dostizheniya tselei ustoichivogo razvitiy, 2019, p. 11). Uniform standards and a curriculum for pre-school education are developed and approved in the country. According to statistics the pre-school coverage of 1-5-year-old children amounts 79,5\% [Belarus' $v$ tsyfrah (Belarus in figures), 2019, p. 17). Therefore, the study of a social situation of preschool children development in the conditions of the family and a group of a pre-school education institution is relevant in the modern changing world.

\section{Materials and Methods}

The research was conducted in order to improve the organization of the educational process; it was agreed with the administration of pre-school education institutions and children's parents, and it was voluntary. The sample of the empirical study comprised middle and older pre-school age educatees of pre-school education institutions $(n=100)$ and their parents $(n=28)$. Diagnostic tools: "Parents composition" (Shvedovskaya, A.A., 2009), "Choice in the action" (Kolominskii Ya.L. and others),1997), "Stair" (V.G. Shchur), 
"Finish a story" (Kalinina R.R.,2005), a conversation on three clusters of unfinished sentences "I and my family", "I and a kindergarten", "I and other people".

\section{Results}

The analysis of the results of the study included several stages.

1. The selection of parameters of relations "child-adult" in the conditions of the family. Initially, based on the results of methodology "Parents composition" which included 30 unfinished sentences, parameters of interaction "parent-child", as a characteristic of a social situation of children development in the conditions of the family, were analyzed. Following the results of the empirical study, the uneven presence of all five types of childparent interaction should be noted: conflict, harmonious, distant and dominant (dependent on the subject of dominance, it is subdivided into the following types: “dominant parent - obedient child", "dominant child - obedient parent”). The distribution of the child-parent dyad is presented in table 1, following the defined types.

Table 1. Types of parent and child interaction

\begin{tabular}{|l|l|c|}
\hline Type & $\begin{array}{l}\text { Pattern of the } \\
\text { interaction }\end{array}$ & \% tested \\
\hline Conflict type & uncoordinated "We" & 10,7 \\
\hline Harmonious type & complementary "We" & 10,7 \\
\hline Distant type & interaction "near" & 10,7 \\
\hline “Parent-dictator" & dominance-submission & 39,3 \\
\hline “Child-dictator" & dominance-submission & 28,6 \\
\hline
\end{tabular}

As can be seen from the table, there is a predominance of non-constructive childparent interaction in the respondents' families: "parent-dictator" $(39,3 \%)$, "child-dictator" $(28,6 \%)$, conflict and distant types of interaction (of $10,7 \%$ each). It is alarming that a harmonious type prevails only in $10,7 \%$ of the families.

A comparative analysis of peculiarities of parents' compositions shows that there are significant differences in the image of a child and relations with him/her in different types of parent-child interaction. In case of a conflict type, parents are mainly oriented on child's external characteristics: physical activity, appearance, peculiarities of communication, achievements, they are concerned about physical well-being and child's disobedience, weak parents' orientation on emotional - personal properties. Conversely, a harmonious type is characterized by parents' orientation on positive personal qualities of a child where the most frequently mentioned child's quality is "kindness". A child's independence is essential for a distant type; parents note a high degree of child's maturity 
compared to peers. A subordinate parent notes well-developed communication and will skills, language stimulation and inquisitiveness in a child; parents of this type speak of their concerns about the child's personal development and their inability to interact. A subordinate parent pays less attention to the individual peculiarities of a child, also noting his/ her accordance with norms, distinct qualities of communication and leadership and, to a lesser extent, propensity for sufferings concerning an interaction with a child.

It should be noted that the received distribution of type distinction, in general, corresponds to data previously obtained by developers of the given methodology on the Russian sampling (Shvedovskaya, A.A., 2009), which proves the opinion that parameters of child-parent interaction are relatively stable despite significant changes that have occurred in the sphere of social relations during the past decade.

The analysis of the perception of child-parents interaction on the part of a child was conducted according to the results of a conversation with children based on the cluster of unfinished sentences "I and my family". It should be noted that all the children are satisfied with their families, give the parents positive features (good, kind, friendly, polite, etc.), and say that they love them. Parents are necessary to "feed, bring up, help, save...children". To varying degrees, all the parents spend the time with a child: play, watch TV, read, go for a walk, go on a visit, travel etc. All the children consider that the main pleasure for the parents is the child's achievements (i.e. their own achievements and correspondence to norms). More than half consider that their parents have everything enough, the remaining name as missing resources - material values, time for rest and communication, their obedience, a missing member of the family. At the same time, practically all the children wish to see their future family the same as their parents' family is.

Thus, the priority to traditional family values is revealed among the children, parents act as significant adults, in general children take the existing types of relationships childparent, at the same time, it can be noted that educational potential of the father is not fully realized (the father is marked as a missing member of the family, not always participating in family interaction).

2. The selection of parameters of relations "child-adult" and "child-peer" in the conditions of an educational institution.

The analysis of the perception of interaction at a pre-school education institution on the part of a child was conducted according to the results of a conversation with children based on the cluster of unfinished sentences "I and other people" and "I and a kindergarten".

It can be noted that both spheres of interaction: "child-adult" and "child-peer" are 
almost equally significant for middle and older aged preschoolers. The children note that they prefer to spend their time with peers, admitting that they have friends, including grown-ups (relatives, acquaintances). To an equal degree, they prefer parents and friends as assistance in difficulties and as partners for discussion of important events. All the children indicate positive characteristics in their educators' image, which can explain their positive attitude to them.

Based on children's replies, it can be noted that a pre-school education institution is in general attractive for children: a possibility of interaction with peers, implementation of game and a productive type of activity. An adult (parent, educator and others) is an idealisation object and implements a function of support.

To reveal objective indicators of a child's position in a group of kindergarten, a type of sociometric methodology, "Choice in the action" was used. A position in the system of relationship was interpreted according to data on the respondent's personal development (self-assessment according to method "Stair", awareness of ethical norms and values "Finish a story").

The analysis of relationships in the studied groups of pre-school education institutions showed that, in general, there is a favorable climate in the given subsystem of relations. Children of the middle and older age are engaged in all types of social interaction with peers; preferences to one or another type of interaction are connected with the self-assessment, a position in a group and a level of awareness of ethical norms and values. Good relations in a group of peers create conditions for children to reveal different types of motivation of social interaction when choosing a partner for concerted actions. Constructive and non-constructive types of motivation of interaction with peers, selected on the basis of an analysis of quality characteristics of choice motives, appeared to be approximately equally expressed (individualism: $24 \%$, competition: $22 \%$, aggression: $4 \%$; cooperation and equality: $20 \%$ each, altruism: $10 \%$ ). In the specificity of a display of a specific type of motivation of social interaction, there are some gender and age differences that correspond to the traditional dynamics of its formation.

Based on percentages of the types of motivation of social interaction, it can be seen that motivation of individualism takes a leading position. It follows that, first of all, the majority of children are eager to satisfy their own interests, motives, get benefits, rather than their partner's motives and furthermore public motives. Thus, social (public) motives and empathy, starting from the middle preschool age, are in the initial development stage. There are some gender differences in the development of motivation of individualism. Children of the middle preschool-age tend to choose a partner for social interaction 
depending on material values that the partner possesses, and a child needs or likes (brings new toys, a scooter, a clipboard). Older pre-school-age children also tend to choose a partner depending on the partner's material values that they like. However, in this case, children pay great attention not just to toys but to access to information technologies and equipment (clipboard, computer, machine), which is connected with a higher level of mastery of these types of technology at the given age. Besides the interest in material values, a motive of self-improvement also acts as an individual motive. Most of all, children tend to choose those children who possess the potential to educate, certain abilities to teach something new and help another child to become better. The given motives are seen very clearly among older pre-school aged girls. A tendency where a child's position regarding the motivation of social interaction is formulated under the parents' pressure and is not independently chosen by a child (parents advice to be friends with a partner, as a child is good) was also revealed. Even trying to receive a selfconsistent reasoned reply from a child, the child is afraid to make the own assessment and operates with difficulty on own points of view and preferences, which is a negative factor in forming an autonomous personality that can take responsibility for their own actions.

Almost equal to individualism, there is a motive of competition in social interaction $(22 \%)$. First of all, the display of the given motive is connected with enhanced development of competitive motives at the middle and older pre-school age. A motive of power is observed in the motivation of competition. Herewith, girls and boys want to gain the given power for different purposes. The girls' purpose is simpler - to attract as much peers' attention as it is possible to themselves. The boys' purpose is more substantial and deeper: not just to attract attention but to get peers' approval and recognition. The given fact demonstrates an increasing demand for peers' approval and recognition.

According to the data of the table, a motive of cooperation takes third place (20\%). It is most clearly seen among the girls of both groups. In reasoning, the choice of cooperation motivation among the children of the middle pre-school age motives of a moral character is most clearly distinguished, where partners have similar moral values ("ability to help each other, share toys with each other"). The girls of the older pre-school age emphasize the ability to share joy, delight, ability to keep each other's secrets, which shows the importance of trustful interpersonal relationships between partners. At the older pre-school age, these are primarily boys who, choosing a peer in the motivation of cooperation, pay special attention to peer's academic, physical abilities ("do practical tasks together, participate in sports competitions, attend the same section, club"). These 
changes indicate the transformation of children's motives, since at the older pre-school age due to necessity to enter school and to master a new social role it is important for a child to show him/herself in other types of activity, the interest grows to positive results of cognitive activity and its high estimation. Also, the cases are observed when a child carries motivation of cooperation over the example from the parent and the peers' parents ("our parents are friends and communicate well with each other that is why we have become friends, too").

Almost on an equal basis, equality motivation follows the motivation of cooperation in social interaction (20\%). In the course of the research, a difficulty arose in the division of motivation of cooperation and motivation of equality, in the detection of their essence and distinguishing characteristics. The children's replies often crossed with characteristics of both the motivations; their distinction was achieved due to more detailed questions. Cooperation - collaboration over the common cause, maximization of common, joint winning in the activity, the summation and combination of forces. Equality - achievement of minimum in differences of winning, positions of peers "on equal" where everyone does not compete but chooses their own way of the development. If cooperation is joint participation in a sport race where the main point is a victory of the whole team, then equality is participation in different types of activity in accordance with skills. For example, one member of interaction takes part in a contest of dances, another - in gymnastics competitions where the winning is minimized, and peers can reach the same level of success in different types of activity. In this type of motivation of social interaction, motives of transfer of their experience to peers and vice versa are observed both among boys and girls ("A. goes in for acrobatics, and I practice dancing, but I can't jump so high as $A$., that is why she teaches me to do it, and I teach dancing"). Along with motivation of equality, the demand for partner's honesty, compliance with rules and justice between them is observed among older pre-school-aged boys. ("he never cheats, plays fair"). Also, the motive of peers' assistance to each other plays a significant role in the motivation of equality.

A motive of altruism appeared to be less noticeable (10\%). Besides, specific gender differences are observed in the content of motivation of altruism. There are two tendencies in the reason of altruism of social interaction: empathy and obligation (acceptance of social values). Herewith, the only experience of empathy and assistance to a peer prevail at the middle pre-school age ("I can calm when she is crying, not in a mood, I can cheer a friend up"). At the older pre-school age, the acceptance of social values is formed on the basis of previous experience: "Why am I helping him? Because 
it should always be done and there is no need to find reasons. Sometimes it happens so that a man can't admit that he needs help because he is shy" (Misha, seven years old). The development of unselfishness and one of the most important personal quality - the ability to empathy is observed in the motivation of altruism.

Two positions of assistance to a peer were detected in the motivation of altruism of social interaction. The position of a partner, a friend, is more represented among children of the middle pre-school age ("I can calm when she is crying, or cheer up if she is not in a mood"). The position of guardianship, "a teacher," is represented among girls of the older pre-school age ("I help to do homework for school preparation, or he/she will do nothing again").

A motive of aggression appeared to be less distinguished. The motivation of aggression was not detected among the girls but only among the boys. Aggression was also represented in two forms. At the middle pre-school age, aggression is represented in a physical form, and at the older age, it is represented in a verbal form. Herewith, sometimes a child is not aware of the illegality of his/her actions referring to the fact that he is taught by the father and at a taekwondo club, then it means that such actions can be performed practically in any social situation and without reasons in order to show own abilities.

\section{Discussion}

The research results make it possible to speak of the availability of different variants of pre-school child's experience of a social situation of the development in the conditions of a family upbringing and attending a group of a pre-school education institution.

The study of the types of child-parents interaction shows relative stability of the family institution in terms of preserving the types of interaction, which have been previously productive even in the conditions of social transformations. The availability of different variants of the social environment facilitates the formation of images of different types of social interaction among children and their transfer into interaction with peers, which is revealed in the motivation of choice in the conditions of education institution.

The results of the research suggest the necessity of organization of targeted psycho-pedagogical support of pre-school aged children in their socialization and acquisition of constructive types of motivation of social interaction in modern social conditions and also the development of a personality in accordance with a motivation type based on the creation of conditions for satisfaction of every child's need for communication and support of social status of childhood. 


\section{Conclusions}

The parameters of a social situation of the development are an important condition of socialization in the period of childhood. The children's perception of various subsystems of interaction "child-adult", represented in the empirical research, can be generally considered positive. A subsystem "child-peer" is intermediated via wider social influence, and it is also an important aspect of the social situation of the development of a pre-school aged child. Optimization of the main parameters of pre-school children interaction in pre-school educational institutions and the family (in the context of the revealed tendencies) is a relevant direction of the support of positive socialization of preschool aged children.

\section{References}

Asmolov, A. G. (2016). Psychology of Modernity as a Social Situation of Development: Challenges of Uncertainty, Complexity and Diversity. Procedia - Social and Behavioral Sciences, 233, 27-34.

https://doi.org/10.1016/i.sbspro.2016.10.122

Asmolov, A.G. (2017) Strakh peremen i novye vozmozhnosti rosta (Fear of changes and new opportunities for the growth). Available online: https://komitetgi.ru/school/obraz-budushchego/3428/ (accessed on Monday, April 19, 2021).

Belarus' na puti dostizheniya tselei ustoichivogo razvitiya (Belarus on the way of achievement of objectives of the stable development) (2019). Available http://www.belstat.gov.by/ofitsialnaya-

statistika/publications/izdania/public compilation/index 12924/ (accessed on Monday, April 19, 2021).

Belarus' $v$ tsyfrah (Belarus in figures) (2019). Available online: http://www.belstat.gov.by/upload/iblock/cf4/cf4915a5e6ade269f20c0bf5 a332a7a3.pdf/ (accessed on Monday, April 19, 2021).

Fel'dshtein, D.I. (2012). Sovremennoe detstvo kak sotsiokul'turnyi i psikhologicheskii fenomen. (The modern childhood as a sociocultural and psychological phenomenon). Universum: Vestnik Gertsenovskogo universiteta, 1, pp. 20-29; ISSN: 2306-9880. 
Gogoberidze, A.G. ; Novitskaya, V.A.; Atarova, A.N.; Novikov, M.S.; Yafizova, R.I. (2018). Doshkol'nik kak sub"ekt proektirovaniya sotsiokul'turnogo prostranstva i obrazovatel'noi sredy svoego razvitiya. Zamysel odnogo proekta (Preschooler as a subject of socioculrural space and educational environment of the development. Idea of one project). Sovremennoe doshkol'noe obrazovanie Modern preschool education], №5 (87), pp. 1623. DOI:10.24411/1997-9657-2018-00018.

Kalinina R.R. (2005). Trening razvitiya lichnosti doshkol'nika: zanyatiya, igry, uprazhneniya (Training of the development of a prescooler's personality: study, games, exercises), 2-e izd., dop. i pererab.; Rech': SaintPetersburg, $160 \mathrm{p}$.

Kolominskii Ya.L. (and others). (1997). Diagnostika psikhicheskogo razvitiya doshkol'nikov (Diagnosticity of psychological development of preschoolers). Diagnostika psikhicheskogo razvitiya doshkol'nikov (Diagnosticity of psychological development of preschoolers).Universitetskae: Minsk, 237 p.; ISBN 985-09-0117-9.

Kolominskii, Ya.; Pan'ko, E.; Chesnokova, E.; Nedvetskaya, T. (2015). Interaction of a six-year-old child with peers. Praleska, 8 (288) (2221-6308), 27-40. https://www.elibrary.ru/item.asp?id=30605226

Polivanova, K. (2016). Childhood in a changing world. (Современная Зарубежная Психология), 5(2), 5-10. https://doi.org/10.17759/jmfp.2016050201

Shvedovskaya, A.A. (2009). Osobennosti perezhivaniya detsko-roditel'skikh otnoshenii i vzaimodeistvie s roditelyami detei starshego doshkol'nogo vozrasta (Pecularities of experience of child-parents' relations and interaction with parents of older preschool-aged children). Sbornik portala psikhologicheskikh izdanii PsyJournals.ru. № 1. Available online: http://psyjournals.ru/pj/2009 1/22858.shtml (accessed on Monday, April 19, 2021).

Smirnova, E.O.; Lavrent'eva, T.V. (2006) Doshkol'nik v sovremennom mire (Preschooler in the modern world); Drofa: Moscow, $270 \mathrm{p}$.

Veraksa Nikolai (2018). Masshtab lichnosti rebenka raven beskonechnosti (The scope of the child's personality is equal to infinity). Available online: https://ecceconference.com/upload/\%D1\%80\%D0\%B5\%D0\%BA\%D1\% 82\%D0\%BE\%D1\%80\%20\%D0\%B2\%D1\%83\%D0\%B7\%D0\%B0\%20\% D0\%B2\%D0\%B5\%D1\%80\%D1\%81\%D1\%82\%D0\%BA\%D0\%B0\%20\% 
D0\%B8\%D0\%BD\%D1\%82\%D0\%B5\%D1\%80\%D0\%B2\%D1\%8C\%D1

\%8E\%20\%D0\%B2\%D0\%B5\%D1\%80\%D0\%B0\%D0\%BA\%D1\%81\%D1

\%8B.pdf (Monday, April 19, 2021).

Veraksa, N.E.; Veraksa, A.N. (2008). Sotsial'naya situatsiya razvitiya v doshkol'nom detstve (Social situation of the development in preschool childhood). Doshkol'naya Pedagogika i Psikhologiya (Preschool Pedagogics and Psychology), 1, Moscow, p.12-21.

https://www.elibrary.ru/item.asp?id=21810206

Vygotskii, L.S. (1984). Detskaya psikhologiya (Children psychology). Sobranie sochinenii v 6 t.: T.4 (Collected works: in 6 vol. Vol.4); Pedagogika: Moscow, 432 p. 